\title{
Stock Market Liquidity and Firm Value- Indian Evidences Manjit Kaur Sidhu
}

(Department of University Business School, Panjab University, Chandigarh, India) (kaur_manjitsidhu87@yahoo.com)

\begin{abstract}
This paper examined the relationship of stock market liquidity on the firm value of Indian manufacturing firms included in the S\&P BSE 100 Index from 2009 to 2012. The random effects panel regression model has been invoked to analyze the relationship. The empirical results support the stock market liquidity implications of firm value, that is, better liquidity of stock of companies results in higher value of the firm. The empirical results put forth that there is a positive relationship between stock market liquidity as measured by Amivest measure (1985) and firm performance as measured by Tobin's $Q$.
\end{abstract}

Keywords: Firm value, stock market liquidity, S\&P BSE 100 Index

\section{INTRODUCTION}

One of the fundamental components of market microstructure is stock market liquidity and has been seen as an issue of interest in the financial literature. High risk of illiquidity results in higher premium in both developed and emerging markets. Stock market liquidity plays an important role on measuring market growth and efficiency (Singh et al, 2015). The enhancement in stock liquidity improves firm's reputation in financial markets and thus leads to increase in firm's value and reduction of capital cost.

There are strong theoretical grounds to infer that market liquidity will positively affect firm performance because shares of stocks are the currency that commands both cash flow and control rights. The tradability of this currency plays a critical role in the governance, valuation, and performance of firms (Fang et al., 2009). In theoretical analyses, it has been shown that liquid markets permit non-blockholders to intervene and become blockholders (Maug, 1998), endorse more efficient management compensation (Holmstrom and Tirole, 1993), trim down managerial opportunism and helps in encouraging trade by informed investors, thus, revamping investment decisions through more informative prices of the shares (Subrahmanyam and Titman, 2001). Therefore, a priori, a positive relation between liquidity and performance is quite conceivable. However, in spite of the large number of theoretical papers predicting liquidity's effect on performance of the firms, there is paucity of systematic empirical investigation in the same area (Fang et al., 2009). The present study pursues to fill this gap in the literature by investigating the liquidity affect on the firm value.

\section{REVIEW OF LITERATURE}

Stock market liquidity means a market where large orders can be executed without incurring a high transaction cost. Liquidity of a stock is generally defined as the ability to trade large volumes with minimal price impact (transaction price), cost and delay. Ahn et al. (2012) empirically investigate whether the low-frequency liquidity measures that are popular among researches capture liquidity effectively and, if they do, which of the proxies measures liquidity best. They used benchmarks from High frequency Data such as Spread benchmarks (quoted spread, effective spread and the realized spread) and Price impact measures (Hasbraick's lambda, 5 minute price impact and adverse selection costs). Along with the High frequency they also utilized Low frequency data such as Spread proxies (Roll's spread, LOT measures, Zeros and Zeros 2) and Price impact Prices [Amihud (2002), Amivest (1985), Paster and Stambaugh (2003)]. They concluded that there is not one universally accepted proxy for liquidity.

Liquidity has been measured using common proxies like bid-ask spread (Chen et al., 2007 ; Chung et al., 2010), trading volume and turnover (Krishna et al., 2012; Malhotra et al., 2012). Although the concept of liquidity is well understood, but choosing the optimal measure has proven elusive (Bertin et al., 2005).

The existing literature on the relationship between stock market liquidity and firm value is far less contentious. On the basis of standard asset pricing models, empirical research has put forth that lower liquidity results in higher required rate of returns which will act as a compensation for bearing the illiquid risk by the investors. The higher required rate of returns given as compensation will lead to a lower value for illiquid firms in the market. It has been demonstrated by Amihud and Mendelson (2008) as well as Odegaard (2007) that the firm's stock market liquidity has an impact on its value. Further, Amihud and Mendelson (2008) opine that corporate policies that enhance liquidity will positively impact market value. Fang et al. (2009) attributes the positive relationship between liquidity and firm value to higher operating profitability and performancesensitive managerial compensation. Authors further investigated the causality effect between liquidity and firm performance and documented the positive impact of liquidity on firm value. Another strand of existing literature 
relating to the impact of liquidity on firm value has analysed the impact of multiple blockholders on the valuation of the firm. For instance, Bharath et al. (2013) contended that firms in U.S. having multiple blockholders have higher valuations, as proxied by Tobin's q, than firms that have single blockholder. Furthermore, Edmans and Manso (2011) developed a model for the determination of the structure of the blockholders that helps in maximizing the firm value and advocated that management can be disciplined by blockholders through trading. In the model developed by authors, it was observed that multiple blockholders trade competitively for profit. The fundamental value of a firm will be revealed due to enhancement in trading as it leads to impounding more information into prices. Thus, it will pressurize management to exert more efforts which will ultimately results in enhancement in the value of the firm. Arabsalehi et al. (2014) investigated the impact of stock market liquidity on companies' economic performance on 97 selected firms listed on Tehran Stock Exchange (TSE) from 2003 to 2012. Authors posits that stock liquidity had a significant positive impact on EVA and Tobin's Q while they found no evidence that liquidity had any significant impact on ROA. Based on the review of literature following hypothesis have been formulated.

$H_{1}: \quad$ There is a significant relationship between stock market liquidity and firm value.

\section{NEED OF THE STUDY}

There are few studies investigating the impact of stock market liquidity on firm performance especially in emerging markets such as India. This study focuses on differences in firm value due to variations in the liquidity of the firm.

\section{OBJECTIVE OF THE STUDY}

4.1 To examine the stock market liquidity in the sample companies.

4.2 To examine the firm value in the sample companies.

4.3 To study the impact of the stock market liquidity on the firm value of the sample companies.

\subsection{Sample Selection and Data Sources}

\section{RESEARCH METHODOLOGY}

A database was built from a selection of 147 financial reports from $1^{\text {st }}$ April, $2009-31^{\text {st }}$ March, 2012. The selection was drawn from PROWESS database maintained by the CMIE (Centre for Monitoring Indian Economy) to collect a random sample of manufacturing companies. The PROWESS database has formed the basis of several publish empirical studies in India. Out of 147 financial reports only 129 financial reports were usable. The cross sectional daily data of shares traded and absolute returns were used in this study. Firm's financial data was obtained from PROWESS. It is a representative sample because random sampling method has been used to select companies. The sample has been arrived at by omiiting companies from the financial services industry. Further, firms with missing information for the certain time periods have been deleted.

\subsection{Variable Definition}

\subsubsection{Liquidity (Independent variable)}

Amivest measure (LR), introduced by Copper, Groth, and Avera (1985), that compares daily returns with daily volume measured in number of shares is used

$$
L R_{i}^{k, m}=\frac{\sum_{k}^{m} V_{i, t}}{\sum_{k}^{m}\left|R_{i, t}\right|}
$$

where,

$\mathrm{Vi}, \mathrm{t}=$ The trading volume for stock $\mathrm{i}$ on day $\mathrm{t}$

$|\mathrm{Ri}, \mathrm{t}|=$ The absolute return for stock $\mathrm{i}$ on day $\mathrm{t}$

\subsubsection{Firm Value (Dependent variable)}

$$
\begin{aligned}
& \text { Tobin's q }=\quad \text { Market value of common stocks }+ \text { Book value of } \\
& \text { preference stock }+ \text { Book value of borrowing }+ \text { Book value } \\
& \text { of current liabilities }
\end{aligned}
$$

Book value of assets

Where, book value of assets includes fixed assets, current assets and investments. 


\subsubsection{Control Variables}

The inclusion of control variables that may influence firm value is considered fundamental..

5.2.3.1 Age - Age controls for learning efforts by company during its life cycle. The older company could differ from younger companies in liquidity. Natural logarithm of years has been taken as control variable. It is measured as for the number of years for which the company has been in existence since incorporation.

5.2.3.2 Firm size - Natural logarithm of firm size have been taken to control for the size of sample companies. Table I presents the summary of key variables used in the present study.

Table I: Summary of Key Variables

\begin{tabular}{|c|c|c|c|}
\hline $\begin{array}{l}\text { S. } \\
\text { No. }\end{array}$ & Acronym & Variable & Definition \\
\hline 1. & $L R$ & $\begin{array}{l}\text { Amivest } \\
\text { Measure }\end{array}$ & $\begin{array}{l}\text { It compares daily returns with daily volume measured in number of shares. } \\
\qquad L R_{i}^{k, m}=\frac{\sum_{k}^{m} V_{i, t}}{\sum_{k}^{m}\left|R_{i, t}\right|} \\
\text { Where, } \\
\mathrm{V}_{i, t}=\text { The trading volume for stock } i \text { on day } t \\
\left|\mathrm{R}_{i, t}\right|=\text { The absolute return for stock i on day } t\end{array}$ \\
\hline 2. & $\begin{array}{l}\text { TOBIN's } \\
Q\end{array}$ & Tobin's $q$ & $\begin{array}{l}\text { Tobin's } q=\text { (Market value of common stocks }+ \text { Book value of } \\
\text { preference stock }+ \text { Book value of borrowing }+ \text { Book value of current } \\
\text { liabilities) / (Book value of assets) }\end{array}$ \\
\hline 3. & $A G E$ & $\begin{array}{l}\text { Company's } \\
\text { Age }\end{array}$ & $\begin{array}{l}\text { Natural logarithm of the number of years for which the company has been } \\
\text { in existence since incorporation }\end{array}$ \\
\hline 4. & SIZ & $\begin{array}{l}\text { Company } \\
\text { Size }\end{array}$ & Natural logarithm of firm's total sales \\
\hline
\end{tabular}

Source: Researcher's own compilation

\subsection{Tools for analysis}

Data was analysed using SPSS 16.0 and EViews 9 software. Random effects panel regression model is employed to study the impact of stock market liquidity on the firm value by using following model:

Where

$$
\text { TOBIN'S Q }=\beta 0+\beta 1 \mathrm{LR}+\beta 2 \mathrm{AGE}+\beta 3 \mathrm{SIZ}
$$

$\mathrm{LR}=$ Stock market liquidity as proxied by Amivest measure for company $i$ for year $t$

TOBIN's Q = (Market value of common stocks + Book value of preference stock + Book value of borrowing + Book value of current liabilities) / (Book value of assets)

AGE = Natural logarithm of the number of years for which the company has been in existence since incorporation

SIZ = Natural logarithm of firm's sales

\subsection{Descriptive Statistics}

\section{EMRIRICAL RESULTS AND DISCUSSION}

Table II provides the descriptive statistics for the variables used in the study. The examination of the result in Panel A shows that TOBIN'S $\boldsymbol{Q}$ varied significantly, ranging from 0.97 to 17.07 with a mean (median) of 3.84 (2.96). In relation to the stock market liquidity observed across the sample companies, Panel B of the table indicates that the mean (median) value of $\boldsymbol{L R}$ is 12.90 (12.79). Further investigations reveals that stock market liquidity as proxied by $\boldsymbol{L} \boldsymbol{R}$ covers a wide range suggesting that sample covers companies having low as well as high stock market liquidity. Panel $\mathrm{C}$ of the table reflects that the average company in the sample is nearly 4 years old, suggesting that the sample companies are relatively young. Average SIZ of sample companies is 11.67 with maximum and minimum values of 9 and 15 respectively. 
Table II: Descriptive Statistics

\begin{tabular}{|l|l|l|l|l|l|l|l|}
\hline \multicolumn{7}{|c|}{ Panel A: Firm Value } \\
\hline $\begin{array}{l}\text { Continuous } \\
\text { Variables }\end{array}$ & $\begin{array}{l}\text { Symbol } \\
\text { used }\end{array}$ & Observations & Mean & $\begin{array}{l}\text { Standard } \\
\text { Deviation }\end{array}$ & Minimum & Median & Maximum \\
\hline Tobin's Q & TOB & 129 & 3.84 & 2.71 & 0.97 & 2.96 & 17.07 \\
\hline \multicolumn{7}{|c|}{ Panel B: Proxy for Stock Market Liquidity } \\
\hline $\begin{array}{l}\text { Continuous } \\
\text { Variables }\end{array}$ & $\begin{array}{l}\text { Symbol } \\
\text { Used }\end{array}$ & Observations & Mean & $\begin{array}{l}\text { Standard } \\
\text { Deviation }\end{array}$ & Minimum & Median & Maximum \\
\hline $\begin{array}{l}\text { Amivest } \\
\text { Measure }\end{array}$ & LR & 129 & 12.90 & 2.53 & 8.04 & 12.79 & 19.17 \\
\hline \multicolumn{7}{|c|}{ Panel C:Control Variables } \\
\hline $\begin{array}{l}\text { Continuous } \\
\text { Variables }\end{array}$ & $\begin{array}{l}\text { Symbol } \\
\text { Used }\end{array}$ & Observations & Mean & $\begin{array}{l}\text { Standard } \\
\text { Deviation }\end{array}$ & Minimum & Median & Maximum \\
\hline Age & AGE & 129 & 3.62 & 0.689 & 1.10 & 3.81 & 4.65 \\
\hline Company Size & SIZ & 129 & 11.67 & 1.379 & 9.15 & 11.43 & 15.35 \\
\hline
\end{tabular}

Note: Results are obtained using SPSS 16.0

Where, Tobin's q, proxy for firm value; $L R$, proxy for stock market liquidity; $A G E$ is natural logarithm of years for which the company has been in existence since its incorporation; SIZ is natural logarithm of total sales

\subsection{Correlation}

Table III reflects the correlation between variables used in the study. The Pearson correlation coefficient between $\boldsymbol{L R}$ and TOBIN'S $\boldsymbol{Q}(r=0.328, p<0.01)$ is statistically significant at one percent level indicating that liquidity have a positive influence on value of the firm. $\boldsymbol{A G E}$ is positively associated with TOBIN'S $Q$, although the correlation is not significant. Further investigations report a positive significant association between TOBIN'S $\boldsymbol{Q}$ and $\boldsymbol{S I Z}(r=0.459, p<0.01)$ advocating that relatively larger firms have high firm value. $\boldsymbol{A} \boldsymbol{G E}(r=0.238)$ and $\boldsymbol{S I Z}(r=0.157)$ have a significant association with $\boldsymbol{L} \boldsymbol{R}$ at one and ten percent level respectively advocating that relatively older and larger firms have high stock market liquidity.

Table III: Correlation Matrix

\begin{tabular}{|l|l|l|l|l|}
\hline Variables & TOBINS Q & LR & AGE & SIZE \\
\hline TOBINS Q & 1 & & & \\
\hline LR & $0.328^{* * * *}$ & 1 & & \\
\hline AGE & 0.007 & $0.238^{* * *}$ & 1 & \\
\hline SIZ & $0.459^{* * * *}$ & $0.157^{*}$ & $0.200^{* *}$ & 1 \\
\hline
\end{tabular}

Note: Results are obtained using SPSS 16.0

***,**,* indicates level of significance at 1,5 and 10 percent respectively. The test of significance is two tailed.

Where, $T O B I N$ ' $S Q$, proxy for firm value; $L R$, proxy for stock market liquidity; $A G E$ is natural logarithm of years for which the company has been in existence since its incorporation; SIZ is natural logarithm of total sales

\subsection{Multivariate results}

The data is a balanced panel, i.e., for each unit (company), three time series data have been observed. Panel data assists in obtaining consistent estimates of the coefficients by controlling the unobservable company heterogeneity that might lead to a spurious relation between dependent and independent variables. Random effects panel regression model has been employed as the $p$-value (0.274) of Hausman test is not significant indicating that random-effects is the appropriate approach for the present study.

The results of random-effects panel regression analysis to determine the effect of stock market liquidity on firm value are presented in Table IV. The results report that $\boldsymbol{L} \boldsymbol{R}$ has a positive relationship with $\boldsymbol{T O B I N} \boldsymbol{S} \boldsymbol{Q}$ with a coefficient of 0.126 significant at five percent level. $\boldsymbol{A} \boldsymbol{G E}$ was found to be positively related to $\boldsymbol{T O B} \boldsymbol{B} \boldsymbol{N} \boldsymbol{S}$ $Q$ but the relationship was not statistically significant. The positive sign of the coefficient of $\boldsymbol{S I Z}(\beta=0.831 ; p<$ 0.01 ) is consistent with the expectation that the larger firms have high firm value. The $\mathrm{R}^{2}$ for the model is 28 percent with a significant Wald statistics $(p<0.000)$ indicating the model fitness. These findings of this paper are similar to the findings of Fang et al. (2009); Wu and Liu (2009) and Singh et al. (2015). 
Table IV: Regression results of Impact of Stock Market liquidity on Firm Value

\begin{tabular}{|c|c|}
\hline Explanatory Variables & Model \\
\hline Intercept & $\begin{array}{l}13.554^{* * *} \\
(0.000)\end{array}$ \\
\hline $\mathbf{L R}$ & $\begin{array}{l}0.126^{* *} \\
(0.023)\end{array}$ \\
\hline AGE & $\begin{array}{l}0.443 \\
(0.375)\end{array}$ \\
\hline SIZE & $\begin{array}{l}0.831^{* *} \\
(0.000)\end{array}$ \\
\hline No. of Observations & 129 \\
\hline Overall $\mathbf{R}^{2}$ & $0.28 \%$ \\
\hline Wald Statistics (F) & 22.63 \\
\hline Prob>chi square & 0.000 \\
\hline
\end{tabular}

Note: Results are obtained using EViews 9

Dependent variable is firm value as captured by Tobins' $Q$.

The p-values are shown in parentheses.

***,**,* indicates level of significance at 1,5 and 10 percent respectively. The test of significance is two tailed.

Where, $T O B I N$ 'S $Q$, proxy for firm value; $L R$, proxy for stock market liquidity; $A G E$ is natural logarithm of years for which the company has been in existence since its incorporation; SIZ is natural logarithm of total sales

\section{CONCLUSION AND IMPLICATIONS}

This paper hypothesizes that stock market liquidity affects firm value. To provide supporting evidence, random effects panel regression model is employed. The study shows that there is positive relationship between stock market liquidity and firm performance as proxied by Tobin's $\boldsymbol{q}$. The results report that $\boldsymbol{L R}$ have a positive relationship with Tobin's $\boldsymbol{q}$ indicating that improvement in stock market liquidity helps in enhancing the value of the firm thus leading to the acceptance of $\boldsymbol{H}_{1}$, i.e., there is a significant relationship between stock market liquidity and firm value. Furthermore, empirical results reveal that the larger firms have high firm value. The findings of this paper are similar to the findings of Fang et al. (2009); Wu and Liu (2009) and Singh et al. (2015). Research findings shed light on the important role of stock market liquidity of the company in improving firm value. Finally, the results of the present study have implications for the managers of the companies who should put their best of efforts to increase stock market liquidity which consequently increases firm value.

\section{LIMITATIONS AND FUTURE RESEARCH}

The present study is restricted to the sample of Indian manufacturing firms which entails that the findings of this study could only be generalized to manufacturing firms similar to those that were included in this research. Also, the size of the sample is small and the period of the study is just three years. Future research should explore the generalizations of the findings of the present study beyond the Indian 
manufacturing sector. Further, significant control variables such as industry sectors, risk, etc., should also be employed. The time period of the study should be extended.

\section{REFERENCES}

[1] T. Singh, M. Gupta, and A. Sharma, Stock market liquidity and firm performance, Accounting, 1, 2015, 29-36.

[2] V. W. Fang, T. H. Noe, and S. Tice, Stock market liquidity and firm value, Journal of Financial Economics, 94, 2009, 150-169.

[3] E. Maug, Large shareholders as monitors: is there a tradeoff between liquidity and control?, Journal of Finance, 53, 1998, 65-98.

[4] B. Holmstrom, and J. Tirole, Market liquidity and performance monitoring, Journal of Political Economy, 1, 1993, 678-709.

[5] A. Subrahmanyam, and S. Titman, Feedback from stock prices to cash flows, Journal of Finance, 56, 2001, 2389-2413.

[6] H. J. Ahn, J. Cai, and C. W. Yang, Which liquidity proxy measures liquidity best in emerging markets? School of Business, Sungkyunkwan University, Jongno-gu, Seoul, Korea, 2012, accessed on $12^{\text {th }}$ march, 2013 at 11.13a.m from www.iksa.or.kr/search/down.php?r.

[7] Y. Amihud, Illiquidity and stock returns: cross-section and time-series results, Journal of Financial Markets, 5, 2002, 31-56.

[8] S. Copper, K. Groth, and W. Avera, Liquidity, exchange listing and common stock performance. Journal of Economics and Business, 37, 1985, 19-33.

[9] L. Pastor, and R. Stambaugh, Liquidity risk and expected stock returns, Journal of Political Economy, $111,2003,642-685$.

[10] W. P. Chen, H.Chung, C. Lee, and W. L. Liao, Corporate governance and Equity Liquidity: analysis of $\mathrm{S}$ and $\mathrm{P}$ transparency and disclosure rankings, Corporate governance, 15(4), 2007, 644-660.

[11] K. H. Chung, J. Elder, and J. C. Kim, Corporate governance and Liquidity, Journal of Financial and Quantitative Analysis, 45(2), 2010, 265-291.

[12]R. Krishnan, and V. Mishra, Intra Liquidity Patterns in Indian Stock Market. Monash University, Department of Economics, ISSN 1441-5429, 2012, discussion paper 34/12.

[13] M. Malhotra, M. M. Then, and A. K. Gopalaswamy, Liquidity changes around bonus and rights issue announcements: Evidence from Manufacturing and Service sectors in India, IJMBF, 1(1), 2012, 28-34.

[14] K. Bertin, and P. Michayluk, Intraday REIT Liquidity, Journal of Real Estate Research, 27(2), 155176.

[15] Y. Amihud, and H. Mendelson, Liquidity, the value of the firm, and corporate finance., Journal of Applied Corporate Finance , 20( 2), 2008, 32-45.

[16]B. A. Odegaard, Price differences between equity classes. Corporate control foreign ownership or liquidity? Journal of Banking and Finance, 31, 2007, 3621-3645.

[17] S. T. Bharath, S. Jayaraman, and V. Nagar, Exit as governance: An empirical analysis. The Journal of Finance, 68(6), 2013, 2515-2547.

[18]A. Edmans, and G. Manso, Governance through trading and intervention: A theory of multiple blockholders. Review of Financial Studies, 24(7), 2011, 2395-2428.

[19]M. Arabsalehi, M. Beedel, and A. Moradi, Economic performance and stock market liquidity: Evidence from Iranian Listed Companies. International Journal of Economy, Management and Social Sciences, 3(9), 2014, 496-499.

[20] C. Wu, and I. H. Liu, Market liquidity, corporate governance and firm value- Taiwan Evidences. National Chengchi University, Taipei, Taiwan, 2009, 1-25. 